\title{
Urbanization in a historical perspective
}

\author{
Elena Zaborova
}

Ural State University of Economics, 8 Marta Str., 62, 620144 Ekaterinburg, Russia

\begin{abstract}
Russia is one of the highly urbanized countries, so the question of the prospects for developing urban processes is very relevant. Currently, there are two processes in our country: the growth of large cities, their transformation into agglomerations, and the reduction in the number of residents of small and medium-sized cities. These processes are unfolding in the new conditions of the information and digital era, which is changing the spatial fixation of the functionality of large cities, taking many traditional urban activities online mode. It creates the basis for moving the population from large megacities to the suburbs or small and medium-sized cities. Computer technologies are being actively introduced into all spheres of life. They are radically changing our lives and allow avoiding many problems of a large city, making typical types of urban life virtual. As a result, large cities lose their spatial localization of traditional historical functions (economic, socio-cultural, transport, etc.) and giving small and medium-sized cities a chance to renovate themselves.
\end{abstract}

\section{Introduction}

In the twenty-first century, urbanization has become a global trend, with an increasing proportion of the world's population living in cities. Russia is a highly urbanized country: more than $74.59 \%$ of the population live in 1117 cities, of which $85 \%$ live in cities with populations of up to 100 thousands (2020) [1].

Two global trends can be seen in the development of urbanization processes in our country: the growth of large cities and their transformation into agglomerations, while at the same time there is a decline in the number of inhabitants in small and medium-sized cities (they are declining both in the country as a whole and in particular territories). Both trends are quite clear.

It should be noted that the scientific and publicist literature provides various assessments of these trends. If the growth of cities and their transformation into agglomerations is assessed as more positive (although there are many difficulties in this process), the decline in the number of inhabitants in small citiesis a mixed assessment: some politicians tend to believe that small cities are not competitive with big cities either in terms of socio-cultural conditions (for work, study, living and leisure) or from the economic point of view (many small cities have exhausted their economic potential, they have no sources of investment and do not have enough money to pay for it). Proponents of this view point out that people are moving from small to large cities and it is a natural historical process. The state cannot financially support small towns and most people will leave them in the near future. Opponents believe that small towns must be preserved. The state must 
pursue a policy that develops small towns. It has been noted that small towns are still social and cultural centers for people living in the surrounding rural areas. Many of them are rich in their history, have more comfortable ecological conditions for living, and they "sew" our large territory and prevent it from turning into empty land.

These are the main current trends in the development of urban processes. But will it continue to develop in the same direction or are there other historical twists and turns possible?

\section{Methods and Methodology}

The presented research is based on empirical data obtained in the course of sociological research conducted by the Department of Applied Sociology of Ural State University of Economics in June-July 2019 by order of Federal Research Center (FSRC) of the Russian Academy of Sciences (RAS). Three focus groups were conducted with representatives of business and the public in two small towns in the Sverdlovsk Region (Sredneuralsk and Irbit), 15 questionnaires were collected and 15 in-depth interviews were conducted with experts - with heads of towns and their deputies, members of the staff of the representative office, the most active representatives of business and the public. Focus groups and indepth interviews were conducted according to the scenario and questionnaires proposed by Federal Center of Theoretical and Applied Sociology of Russian Academy of Sciences( FCTAS RAS, Moscow).

The work is also based on statistical materials provided by the State statistical authorities.

Numerous works of Russian and foreign authors devoted to the problems of urbanization serve as the conceptual basis of the work. The originator of the term "agglomeration" is considered to be geographer M. Rouget (1973). Today there are a large number of definitions of agglomeration (Animitsa E. G., Bogorad D. I., Davidovich V. G., Lappo G. M., Pertsik E. N., Petrov N. V., Polyan P. B., Selivanova T., etc.)in general coincident in their content: "an urban agglomeration is a compact and relatively developed set of complementary urban and rural settlements grouped around one or several powerful core cities and United by diverse and intensive connections into a complex and dynamic unity. It is the area, the space of potential and real interactions, which fits the weekly life cycle of the majority of inhabitants in a contemporary large city and its satellite zone." [2]. In the modern scientific literature, there are many approaches that fix the stages of agglomeration formation (works by Lyubov V. ya.,Pchelintsev O. S. [3], Neshchadin A. A. [4]).

Among the Russian authors who study the problems and trends in the development of small towns are V. G. Ledyaev, V. V. Markin, I. A. Medvedeva, O. Podvintsev, P. Panov, D. G. Seltser, V. A. Sukhoi, M. F. Chernysh, A. E. Chirikova, and others.

The prospects of urbanization processes are studied in the works of such authors as Animitsa E.G., VlasovaN.Yu., Vereshchagin T.A., Vorobieva L.A., DegtyarevP..Ya.,Karpenko E. V., Tyunin A., VlasovaN.Yu. I.V., Karpenko E.V., Tyunin A.I. The questions about the development of urabanization processes under the influence of the modern information-digital epoch are currently only being raised in scientific literature, so they require deep studies [5].

\section{Results and Discussions}

In the scientific literature, social forecasting is often based on the extrapolation of strongly pronounced trends for the future, although it is stated that such a forecast does not guarantee a hundred percent probability: life can make significant adjustments. According to the Spatial Development Strategy, there are about 40 large urban agglomerations in the 
Russian Federation, most of which have been steadily growing since the early 2000s and now exceed 73 million people [6]. The development of agglomerations is picking up. So, if we assume that agglomerations will continue to grow successfully and occupy more and more territories, we can logically come up with the idea of a single world city, the author of which is considered to be Greek scientist K. Doxiadis (1914-1975), who put forward the idea of an ecumenopolis - a world city that will take up all the spaces suitable for living. However, it is worth remembering the fact that every large city is a tangle of concerns and contradictions. It provides many opportunities for people, but also often takes and threatens them. For example, a large crowded population is a favourable environment for pandemics, as the current epidemic situation with COVID-19 has shown convincingly. A large number of people do not guarantee an abundance of friends and acquaintances, does not rule out the phenomenon of loneliness in the crowd. Employmentopportunities give rise to the problem of choosing a profession and the need to constantly improve, study, which creates permanent stress. Comfortable living conditions break citizens of working physically, deprive children of labor education. The ease of transport accessibility has long developed into a problem of urban traffic jams and environmental pollution, turned cities into settlements for which there is no place for a person, but the car is comfortable enough.The abundance of information stream leads to information overload and the problem of choosing information. This list can be continued, because in fact we are dealing with the law of medals: every medal has its reverse, so every city has a positive side, and a negative one.

Scientists do not immediately notice these negative aspects, and politicians do not always respond quickly to them. It is enough to recall the story of Jane Jacobs, who in her classic work "The Death and Life of Great American Cities" was the first to draw attention to the fact that the city should not belong to cars, but on a well-organized city street should be everything that provides for the well-being of people [7]. However, in urban planning, the factor of economic feasibility often dominates the human factor, the urban environment is assessed in terms of economic benefits, and not the needs and comfort of people.

In addition to the ambiguous attractiveness of large cities, there is another limit to the emergence of a global city: agricultural and natural. People cannot do without food and need to grow it on fields and farms, they need air and water and therefore they need forests and swamps. The fact that not all people want to live in the 'concrete jungle' must also be taken into account. Many people want to live among nature and be less affected by the urban environment. Thus, the idea of a single world city is unlikely to come true in the near future.

As for the second trend, in 2020 there were 794 small towns in Russia with populations of up to 50,000 [8]. These data eloquently record the problem of spatial and territorial settlement of our country's population. There are many small towns and few inhabitants in Russia. The overwhelming majority of small towns in the Russian Federation are experiencing a decline in the population of small towns by about - 3\% per year. While 48 small towns have a very acute demographic problem: their population is declining at a rate of more than $-3 \%$ (for some cities up to $-11 \%$ per year), that leads to the threat of their extinction [9]. Given this trend, it would be logical to assume that they will disappear off the face of the earth in the future. However, even this trend is currently being slowed down by a number of new phenomena that make it possible to assume that small and mediumsized towns have good historical prospects.

Firstly, there is the relative prosperity of small towns included in the urban agglomeration system. For example, in the Sverdlovsk Region, with the general trend of decline in the number of inhabitants in small towns from 2007 to the present day, five towns have increased their number - Berezovsky, Zarechny, Sysert, Sredneuralsk and Aramil, which are improving their socio-economic situation. 
Secondly, scientists have formulated the main, strategic directions in which small towns can be resuscitated. Their prospects lie in the direction of becomingcenters:

a) processing agricultural products and preserving the small town as a centre for social and cultural services (hospitals, polyclinics, service centres, large shopping centres, theatres, etc.). In the Sverdlovsk Region, an example of such development is the small town of Irbit, which has a population of just over 36,000 people. In the Sverdlovsk Region, an example of such development is the small town of Irbit, which has a population of just over 36,000 people (2020) and is home to the largest dairy plant in Irbit.

b) development of a small town as a tourist centre. Both the historical past of the city and its modern achievements that attract tourists (e.g. eco-tourism) may serve as a basis for such tourist activity. In the Sverdlovsk region, as an example of this direction of development, the city of Verkhoturye can be called, which was formed in 1598 and for a long time served as a center for collecting duties.

c) small town as a Science City. Today, the information and digital era is picking up the pace, which involves the creation of powerful centers for the development of science and technology. In our country, according to the Federal law "On the status of the science city of the Russian Federation" dated April 7, 1999 No. 70-FL, 14 cities (technopolises) have received the official status of a Science City. But there is also a more extended list,which, along with science cities, includes other spatial localization points for innovative production, scientific search centers and digital technology development. Currently, there are more than 70 such localization points [10] and their distribution, according to our calculations, is as follows: $36.6 \%$ - small towns and city districts; $26.8 \%$ - medium-sized towns; $15.5 \%$ - large towns; $2.8 \%$ - cities.

d ) small town as a recreation center. Such undoubted advantages of a town as clean air, silence, and often proximity to water sources or woodlands, combined with other factors (hot springs, therapeutic mud). These factors allow a small town to develop in this direction.

e) a small town as a branch of industrial corporations. In this case, separate production cycles are transferred to the small town, which is beneficial both for the company that does not pay large taxes and for the small town that can offers open vacancies. So, it can be considered like an incentive young people to stay in their home town.

No doubt, there may be other reasons for developing towns. For the renovation of small towns in these or other directions, it is important to find "your idea" and formulate it. It is the first step that each small town must find on its own, as each town is unique. In the past, small towns could not even think about their development strategy as a whole, since their development was largely determined by the centralized policy of the party and government. For example, many small towns in the Urals appeared as settlements around factories, which became city-forming enterprises around which all life in the city was concentrated (the factory had its own housing stock, its own children's pre-school institutions, a factory polyclinic, recreation centers, etc.), and the majority of residents worked at the factory. Today, however, many of these enterprises are outdated, uncompetitive or have ceased to exist at all. As a result the life of a small town is slowing down. Such small towns belonging to monocities, require a particularly careful and attentive approach, as their restoration faces a whole series of problems (outdated equipment, destroyed infrastructure, lack of qualified personnel, outflow of young people, etc.). However, it should be noted that the algorithm for the renovation of small towns only begins with an idea (or choice of a strategic direction that will lead to development). The next step is the joint activity of the authorities, business and the population, as all actors must be involved in the small town renovation processes. Today, the technology for restoring small towns still needs to be developed, and the algorithm for action has not yet been clearly defined. 
Small towns also have a chance for renovation, which is due to another emerging trend in urbanization - the loss of historical functions by large cities as the digital information era increases.

In the history of mankind, large cities have always performed a number of important functions, which have determined such rapid development of cities in our time. Cities have acted as centers in relation to other types of settlements: centers of population concentration, industry, finance, culture, power, transport and logistics flows, fashion and innovation. The larger a city was, the more diverse and richer its functions were. For example, the city of Yekaterinburg, the capital of the Sverdlovsk Region, according to the city development strategy until 2030, combines a number of functions, such as a Russian center of education, high-tech production and service. It ensures the competitiveness of the city economy and the comfort of the city space for the population. The city is alive and well as long as it performs these functions. However, the modern information and digital era is causing the process of transferring these functions into a virtual environment. It, in turn, makes life in the space of a large cityunnecessary. Thus, due to the advent of software systems, the introduction of robots and other information technology innovations, an increasing number of work operations no longer require the direct presence of a person in the workplace, i.e. at a factory or firm. Employer can perform his work remotely. It means there is a basis for gradual spatial modification of one of the most important functions of the city - production, taking it beyond the limits of urban space [11].

Information and digital technologies are being implemented very actively in the financial sector. Today, almost all banking financial operations can be carried out remotely; banks today are virtual financial centers. After the decline in the self-isolation regime, a number of Russian banks decided not to come back to the previous order of work - the need to come to work, as it was quite possible to do work from home without reducing its quality.

The most important function of cities is the trade function. Nowadays, more and more people make purchases through the Internet and online payments. The pace of such purchases is increasing. The digital era is also breaking through to other areas of life in the city, modifying them and undermining the very need to live in the space of the city. Processes are actively going on in medicine, education and culture. The Internet provides access to libraries, as well as to concerts, performances, films and sports competitions, which means that it is possible to join them regardless of a person's spatial location. In the result developing digital information processes, large cities are gradually losing the spatial fixation of their functions in the urban environment. It allows people to move to other spaces - suburbs or small towns.

Of course, this movement is due to a number of special economic and sociopsychological qualities that a person must possess. Thus, the material security factor is important. Modern technologies make it possible to build a fully comfortable detached house in a small town, which is as good as city housing in terms of its characteristics. But for it a person must be financially secure. They also have to go through a special stage of life, when children have grown up and do not need to attend elite schools every day (although this issue is already being addressed through distance learning today). He or she must have a job that allows him or her to work remotely, and therefore he or she is an educated person with high qualifications. These and other characteristics show that initially "moving out of town" will be accessible for the upper and middle class. This tendency we can see now, although not on a massive scale.

\section{Conclusions}

It should be noted that not all of the processes mentioned above can be assessed positively in terms of their quality or in terms of new problems that arise. For example, 
scientific literature has repeatedly emphasized the fact that group distance education in higher education does not guarantee its high quality, as it excludes direct interaction between the student and the teacher. It means that it is impossible for the teacher to assess the situation during a class, to understand the degree of learning of the material, and to react to individual student behavior. Distance education also means that students are highly motivated to learn, self-organized, disciplined and sufficiently ready to learn independently. Not all students have these qualities. However, it is clear that each new process has its own problems and disadvantages. Society eventually adapts and will solve these problems one way or another. It is important to emphasize that digital information processes are unavoidable andirresistible. It should be accepted as a given.

The state of modern transport can be called as a factor constraining the marked trend in the development of urban processes. It is known that many citizens would like to enjoy all the benefits of a city, but at the same time avoid of its noise, polluted air, large crowds of people, the dangers of catching a virus, and alsowasting time in traffic jams. Therefore, wealthy citizens choose the option of living in a 30-minute or even 1.5-hour transport distance from a downtown, getting to it, usually by car. However, the information and digital era is already moving towards to solution to this problem-there is an intensive development of individual air transport - the "flying Board" and "flying motorcycle".

To sum up, it is undoubtedly impossible to expect that the announced trends will be quickly implemented. On the contrary, today the growth of large cities is at its peak. However, we cannot ignore the intensively growing processes of the digital information age, which are qualitatively changing our lives. These processes are very active and the marked prospects can be realized by historical standards very quickly.

The cities are full of negative aspects, and as F. Engels wrote, "...in the face of large cities, civilization left us a heritage that will take a long time and effort to avoid it. But they have to be eliminated - and they will be eliminated, at least it was a very long process" [12].

Metropolises have played an extremely important role in civilization, but it seems that their time is running out and new dominant forms of human settlement are arising.

\section{References}

1. List of Russian cities by population, https://all-populations.com/

2. G. Lappo, P. Polyan, T. Selivanova, Bulletin of the Regional Development Fund of the Irkutsk Region, 1, 46 (2007)

3. V. Lyubovny, O. Pchelintsev, Problems of Forecasting, 5 (2006)

4. A. Neshchadin, Society and Economy, 12 (2010)

5. E. Zaborova, Bulletin of the Perm National Research Polytechnic University, Socioeconomic sciences, 2 (2020)

6. Strategies for the spatial development of the Russian Federation for the period up to 2025, https://all-populations.com/

7. J. Jacobs, The Death and Life of Great American Cities (1961)

8. Cities of Russia, https://ru.wikipedia.org/wiki

9. Concept of the Federal Target Program "Socio-economic development of small towns of the Russian Federation for the period 2015-2020", http://mert.tatarstan.ru/

10. Overview of the largest science cities in Russia, https://viafuture.ru/

11. E. Zaborova, T. Markova, New Industrialization: Global, national, regional dimension (2018)

12. F. Engels, Op. 2nd ed., 20, 309 (1961) 